九州大学学術情報リポジトリ

Kyushu University Institutional Repository

Some Notes on the Genus Osmia of Eastern Asia with a New Synonym (Hymenoptera, Megachilidae)

Tadauchi, 0samu

Xu, Huan- $\mathrm{i}$

Lee, Chang Eon

https://doi.org/10.5109/2592

出版情報: ESAKIA. 35，pp.223-225，1995-01-31. Entomological Laboratory，Faculty of Agriculture, Kyushu University バージョン：

権利関係 : 


\title{
Some Notes on the Genus Osmia of Eastern Asia with a New Synonym (Hymenoptera, Megachilidae)11,2)
}

\author{
Osamu TADAuchI \\ Entomological Laboratory, Faculty of Agriculture, \\ Kyushu University, Fukuoka, 812 Japan \\ Xu Huan-LI \\ Institute of Zoology, Academia Sinica, Beijing 100080, China \\ and \\ Chang Eon LEE \\ 615-2, Hyo Mok 2 Dong, Dong Gu, Taegu 701-032, Korea
}

\begin{abstract}
Osmia (Chalcosmia) imaii Hirashima is newly synonymized with Osmia (Chalcosmia) jacoti Cockerell described from China. Three species of the genus Osmia are recorded from Korea.
\end{abstract}

\section{On Osmia (Chalcosmia) imaii}

Osmia (Chalcosmia) imaii was described by Hirashima in 1973 based on specimens discovered in Hyogo Pref., southern Japan. He wrote some Chinese specimens collected in Beijing might be conspecific with imaii and it might be a recent immigrant to Japan from China by trade of timbers. After that, the species has been introduced from Hyogo Pref. to Fukuoka City for the study of biology and also has been collected from some other places in Kyoto, Fukui, Shimane and Saitama Prefs. In the present study we examined the type specimen of Osmia (Chalcosmia) jacoti deposited in the National Museum of Natural History, Smithsonian Institution, Washington, and many specimens named as jacoti collected in China preserved in the Institute of Zoology, Academia Sinica, Beijing. We recognize Osmia (Chalcosmia) imaii Hirashima is synonymous with 0 . (C.) jacoti Cockerell.

1) Contribution from the Entomological Laboratory, Faculty of Agriculture, Kyushu University, Fukuoka 812 (Ser. 4, No. 88).

2) Partial result from the Korea-Japan Co-operative Science Program on "The Evolution and Biogeography of the Insects in the East Asia”. No. 24. 


\section{Osmia (Chalcosmia) jacoti Cockerell}

Osmia (Chalcosmia) jucoti Cockerell, 1929, Entomologist, 62: 205 [female, China: Tsinan]; Xu et al., 1994, J. Fruit Sci., 11: 153.

Osmiu (Chalcosmia) imuii Hirashima, 1973, J. Fac. Agr., Kyushu Univ., 18: 64 [female \& male, Japan: Hyogo and Fukuoka Prefs., China: Beijing]; Kakutani, 1986, in Bachelor thesis to Fac. Agr., Kyoto Univ.; Haneda, 1987, Hym. Comm., Fukui, (27): 1-2; Maeta \& Sugiura, 1988, Sukashiba, Matsue, 30: 4; Kusumoto, Pulex, Fukuoka, (76): 372. new synonym.

Specimens examined: [China]: type female of jucoti, Tsinan, China, 7. iv. 1928 (A. Jacot). Beijing: 3 females, 24. iv. 1962 (Mao Tinglong); 1 male, 1. iv. 1963 (Wu Yanru); 3 males, 13. iv. 1963 (Chen Tailu); 2 males, 18. iv. 1963 (Ge Shumei); 11 females, 6. v. 1963 (Chen Tailu); 1 female, 15. v. 1964 (Ge Shumei); 3 females, 27. iv. 1973 (Wu Yanru). Hebei Prov.: 9 females, Changli, 28. iv. 1962 (Chen Tailu). Tiangsu Prov.: 2 females, Nanjing, 25. iv. 1935 (0. Piel). Inner Mongolia: 1 female, Qinshuibe, 18. v. 1989 (Xu Huanli). Shandong Prov.: 1 female and 1 male, Weihai, 20. iv. 1993 (Xu Huanli). [Japan]: holotype female of imuii, 10 paratopotype females and 10 paratopotype males of imuii, rared from trap nests, Himeji, Hyogo Pref., iii. 1973 (K. Imai).

Distribution: China (Beijing, Hebei, Tiangsu, Shandong, Provs., Inner Mongolia) and Japan (Honshu: Saitama, Kyoto, Hyogo, Shimane Prefs., Kyushu: Fukuoka Pref.).

\section{Records of Korean species of the genus Osmia}

Four species of the genus Osmiu were recorded from Korea (Kim, 1970), i.e. Osmiu (Osmiu) excavata Alfken, 0. (0.) pedicornis Cockerell, 0. (0.) cornifrons Radoszkowski, and 0. (Cryptosmiu) sutoi Yasumatsu et Hirashima. One of the authors, Tadauchi, collected 3 species in Korea during the Korea-Japan Co-operative Science Program in 1991 and 1992, one of which will be described in a separate paper.

\section{Osmia (Osmia) cornifrons (Radoszkowski)}

Specimens examined: [Korea]: Cheon-La Nam Do: 2 males, Sim Won Valley, Nan Nae Meon, Nam Weon Gun, 13. v. 1991 (0. Tadauchi). Cheon-La Buk Do: San Lyong Li, San Nae Meon, Nam Weon Gun: 1 male, 15. v. 1991 (Malaise trap); 1 female, 29. iv. 1992 (0. Tadauchi, Syringa reticulata); 1 female, 2. v. 1992 (0. Tadauchi); 1 male, 2. v. 1992 (0. Tadauchi, Weigela florida). Kyon Sang Nam Do: 1 female, Sam Jeon Li, Ma Cheong Myon,Hamyang Gun, 1. v. 1992 (0. Tadauchi, Potentila frugurioides var. sprengeliana). Kyonggi Do: 1 female, Kang Nung, Pochon Gun, 19. v. 1992 (0. Tadauchi, Lonicera muuckii). Kang Weon Do: Gam Jong Li, Dong Myon, Chun Chon Gun: 1 male, 25. iv. 1992 (0. Tadauchi, Brussicu napus); 2 females, 21. v. 1992 (0. Tadauchi, L. muиckii, Chelidonium majus); 1 male, Boug Myong Li, Dong Sam Myon, Chun Chon Gun, 26. iv. 1992 (T. Saigusa).

Distribution: Ussuri, Korea, Japan.

\section{Osmia (Osmia) pedicornis Cockerell}

Specimens examined: [Korea]: Cheon La Nam Do: Sim Won Valley, Nan Nae Meon, Nam Weon Gun: 1 male, 13. v. 1991 (0. Tadauchi); 1 male, 29. iv. 1992 (0. Tadauchi, Spirueu 
prunifolia var. simpliciflora). Cheon-La Buk Do: 1 male, San Lyong Li, San Nae Meon, Nam Weon Gun, 2. v. 1992 (0. Tadauchi, W. florida). Kyonggi Do: Kang Nung, Pochon Gun: 1 male, 23. iv. 1992 (0. Tadauchi, Rubus pungens var. oldhami); 1 female, 19. v. 1992 (0. Tadauchi, Elaeagnus multiflora). Kang Weon Do: Boug Myong Li, Dong Sam Myon, Chun Chon Gun: 1 male, 26. iv. 1992 (0. Tadauchi, Taraxacum sp.); 1 male, 26. v. 1992 (T. Saigusa); 1 female \& 1 male, Pupan Myon, Hong Cheon Gun, 20. v. 1992 (0. Tadauchi, Potentilla freyniana).

Distribution: China, Korea, Japan.

\section{Osmia (Chalcosmia) sp. 1}

Specimen examined: [Korea]: Kyonggi Do: 1 female, Kang Nung, Pochon Gun, 23. iv. 1992 (0. Tadauchi, Rubus pungens var. oldhami).

\section{Acknowledgments}

We express our hearty thanks to Prof. Emeritus Y. Hirashima of Kyushu Univ. for his kind help for the study, to Dr. R. J. McGinley of National Museum of Natural History, Smithsonian Institution, Washington, for lending the type specimen of Osmia jacoti. We are indebted to Prof. K. Morimoto and Prof. T. Saigusa of Kyushu Univ. for their various help in the Korea-Japan Co-operative Science Program.

\section{R eferences}

Cockerell, T. D. A., 1929. Red-haired bees from China. Entomologist, 62: 205-207.

Haneda, Y., 1987. On the distribution of three species of bees and sphecids. Hym. Comm., Fukui, (27): l-2 (In Japanese).

Hirashima, Y., 1973. Two new species of the genus Osmia from Japan and N. China (Hymenoptera, Megachilidae). J.Fac. Agr., Kyushu Univ., 18: 63-68.

Kakutani, T., 1986. Analysis of interaction between flowers and pollinators. Bachelor thesis to Fac. Agr., Kyoto Univ., 70pp (In Japanese).

Kim, C-w., 1970. Illustrated Fauna \& Flora of Korea 11(3).835pp., Seoul.

Kusumoto, K., 1988. (Hym.: Megachilidae) Recollecting of Osmia (Chalcosmia) imaii Hirashima from Fukuoka Prefecture. Pulex, Fukuoka, (76): 372 (In Japanese).

Maeta, Y. \& N. Sugiura, 1988. Bees of San-in Districts (1) Megachilidae. Sukashiba, Matsue, 30: 1-10 (In Japanese).

Xu H-l, W-r. Zhou, S. Wei, T. Wang \& Y-r. Wu, 1994. Biological study on pollinators of fruit trees -Osmia jacoti, Osmia excavata. J. Fruit Sci., 11: 153-156 (In Chinese with English summary).

Yasumatsu K. \& Y. Hirashima, 1950. Revision of the genus Osmia of Japan and Korea (Hymenoptera: Megachilidae). Mushi, 21: 1-18, 3 pls. 